\title{
Tłumaczenie antroponimów sztucznych na przykładzie francuskiego $i$ angielskiego przekładu powieści „Pod Mocnym Aniołem” Jerzego Pilcha
}

\author{
Kinga Strzelecka-Pilch \\ Uniwersytet Jana Kochanowskiego w Kielcach \\ kingastrzelecka@wp.pl
}

\section{Streszczenie}

Artykuł porusza problem tłumaczenia antroponimów sztucznych na przykładzie francuskiego $i$ angielskiego przekładu powieści „Pod Mocnym Aniołem” Jerzego Pilcha. Celem pracy jest odpowiedź na pytanie $w$ jaki sposób tlumaczone sa nazwy własne osobowe, które z natury rzeczy nie posiadaja swoich ekwiwalentów uznanych $w$ językach docelowych oraz jakie techniki tłumaczenia przewazaja $w$ ich przekładzie. W tym celu autorka przeanalizowała techniki ttumaczenia zastosowane wobec antroponimów sztucznych $w$ dwóch przekładach powieści i zbadała zwiazek pomiędzy forma nazwy osobowej a wyborem tlumacza. W przekładzie tej kategorii nazw dominujaca technika okazało się być tlumaczenie syntagmatyczne; na 30 nazw wlasnych z tekstu oryginalnego przetlumaczonych $w$ ten sposób zostało 18 antroponimów wjęzyku francuskim $i \quad 19$ w języku angielskim. Pozostałe zidentyfikowane techniki to kolejno: thumaczenie syntagmatyczne z reprodukcja, reprodukcja, ekwiwalent funkcjonalny, pominięcie i dodanie. Nazwy bohaterów wykreowane przez pisarza sq wymagajace $w$ thmaczeniu, ponieważ tłumacz nie może oprzeć się na żadnym użytym wcześniej sposobie ich tłumaczenia i stanowia wyzwanie, zwłaszcza kiedy sq silnie zwiazane z kultura języka docelowego.

Stowa kluczowe: tlumaczenie, przekład literacki, nazwa własna, antroponim, Jerzy Pilch

Abstract

Translation of Fictive Anthroponyms From Polish into French and English on the Example of „Pod Mocnym Aniołem” by Jerzy Pilch

The aim of this work is to present the problem of translation of fictive anthroponyms on the example of French and English version of „Pod Mocnym Aniołem” by Jerzy Pilch by answering the questions: how those fictive anthroponyms are translated and which techniques are used the most often. For this purpose, we analyze translation techniques of anthroponyms in French and English and the connection between the form of an anthroponym and the translator's choice. In this category, literal translation has the highest frequency (18 French and 19 English names of the total 30), the other techniques are literal translation with 
borrowing, borrowing, functional equivalent, reduction, and addition. The names of all characters created by the writer are difficult to translate because those elements do not have any equivalents known by the culture of the target language.

Keywords: translation, literary translation, proper name, anthroponym, Jerzy Pilch

\section{Wstęp}

Antroponim (z greckiego anthropos - człowiek, onoma - nazwa) to nazwa własna, która służy do opisu jednostkowej osoby, w związku z tym posiada jeden desygnat (Kosyl 1993: 423). Sarah Leroy (2004: 33) określa antroponimy jako najbardziej typowy rodzaj nazwy własnej. Nazwy własne charakteryzują się tym, że z reguły pisane są wielką literą. Kryterium wielkiej litery służy do rozróżnienia nazw własnych od nazw pospolitych jedynie w języku pisanym (Leroy 2004: 8-10). Nazwy pospolite, które tworzą antroponimy są pisane małą literą, ponieważ nazwa oznaczająca osobę może być zbudowana z samej nazwy własnej, jak na przykład imię Asia lub też z połączenia nazwy pospolitej i nazwy własnej. W przypadku antroponimów nazwa pospolita - appellativum może mieć postać apelatywu pan/pani; nazwy określającej funkcję lub urząd konkretnej osoby - doktor, terapeuta.

Jak każda nazwa własna, nazwy osób i miejsc nie posiadają słownikowego znaczenia. Jeśli konkretna nazwa własna pojawia się w słowniku, występuje tam jako przykład ilustrujący daną kategorię, lub w przypadku derywatu słowo, od którego pochodzi (Leroy 2004: 11-13). Kolejną cechą, która różni nazwy własne od nazw pospolitych jest to, że te pierwsze nie posiadają liczby mnogiej. Dodatkowo sposób w jaki denotują różni się od nazw pospolitych. Kleiber w artykule Sur le rôle cognitif des noms propres (2007: 153-167) zaznacza, że nazwa własna w przeciwieństwie do nazwy pospolitej jednocześnie służy do określenia konkretnego desygnatu, jak i nosi jego imię, podczas gdy nazwa pospolita służy do określenia różnych desygnatów, ale nie nosi jednostkowego imienia żadnego z nich.

Czesław Kosyl w artykule Główne nurty nazewnictwa literackiego (1993: 67-100) dokonał podziału nazw własnych występujących w dziełach literackich ze względu na ich genezę. Wyróżnił nazwy realistyczne stworzone przez autora w zgodzie z zasadami danego języka, nazwy konwencjonalne zaczerpnięte z innych utworów literackich; nazwy autentyczne, czyli nazwy postaci historycznych i miejsc rzeczywistych oraz nazwy sztuczne, które są wytworami autora i nie należą do zbioru nazw danego języka. I właśnie ta ostatnia kategoria nazw i jej przekład jest tematem niniejszego artykułu. 
Antroponimy $\mathrm{W}$ tekście literackim funkcjonują inaczej niż $\mathrm{w}$ rzeczywistości pozatekstowej. Kosyl (1992: 50) wyszczególnił ich następujące funkcje:

1) Funkcja identyfikacyjno-dyferencjacyjna. Identyfikacja to podstawowa funkcja nazw osobowych w tekstach literackich i w rzeczywistości. Pozwala na wyodrębnienie konkretnej jednostki spośród innych. Dyferencjacja natomiast umożliwia odróżnienie bohaterów w określonym dziele literackim.

2) Funkcja lokalizacji w czasie. Antroponimy autentyczne bohaterów działających użyte w powieści pozwalają czytelnikowi na zidentyfikowanie czasu akcji bez bezpośredniego wymieniania dat, na przykład nazwisko Stalin przenosi czytelnika w określony czas i przestrzeń. Ten zabieg jest możliwy wtedy, kiedy autor i czytelnik dzielą tę samą wiedzę historyczną.

3) Funkcja socjologiczna. Nazwa własna może wskazywać na obce pochodzenie narodowe bohatera. Ta sama funkcja może wskazywać na pochodzenie społeczne bohaterów.

4) Funkcja aluzyjna. Wyodrębnione zostały trzy typy aluzji: treściowa, onomazjologiczna oraz onomastyczna. Należy podkreślić, że jedna nazwa może pełnić w tekście kilka różnych funkcji.

Powieść „Pod Mocnym Aniołem”, wydana w 2000 roku, obfituje w nazwy osobowe, choć sama powieść liczy 200 stron autor wprowadza wielu bohaterów lub odwołuje się do nich. Nazwy sztuczne stanowią najmniej liczną kategorię nazw (30 spośród 126 wszystkich antroponimów), jednak są szczególnie interesujące, ponieważ wiele z nich zawiera informacje o postaciach, które je noszą, np. Przewodnik Pracy Socjalistycznej, terapeuta Mojżesz alias Ja Alkohol, Asia Katastrofa, Alberta Lulaj. Są również dowodem innowacyjności językowej pisarza, a co za tym idzie stanowią wyzwanie dla tłumacza. Autorką francuskiego przekładu „Sous l'aile d'un ange” wydanego w 2003 roku jest Laurence Dyèvre, autorem amerykańskiej wersji powieści „The Mighty Angel” z 2009 roku jest Bill Johnston. W pracy porównano techniki tłumaczenia użyte w obu wyżej wymienionych przekładach, dokładny spis prezentuje tabela w aneksie.

\section{Techniki tlumaczenia antroponimów sztucznych z powieści „Pod Mocnym Aniołem"}

Technika tłumaczenia według Hejwowskiego (2004: 92) to rodzaj postępowania, jaki wybiera tłumacz wobec konkretnej nazwy własnej. Małgorzata Łukasiewicz podkreśla, że nazwy własne w przekładzie literackim są bardzo charakterystycznym nośnikiem obcości (2017: 96), 
zarówno Łukasiewicz (2017: 97), jak i Urszula Dąmbska-Prokop (2010: 270-271) podkreślają, że nazwy własne, w tym antroponimy pozostają na ogół w formie tekstu wyjściowego, czyli w swojej oryginalnej formie i niejako nie podlegają tłumaczeniu, jednak istnieją wyjątki. Przekładane są nazwy znane kulturze języka docelowego. Wynika stąd, że wybór techniki tłumaczenia może być ograniczony kulturowo. We współczesnym przekładoznawstwie istnieje hipoteza, że w przekładzie nazw własnych coraz mocniej dominuje tendencja używania technik egzotyzujących i z czasem odchodzi się od technik udomawiających. Jerzy Święch w artykule Przekład na warsztacie badacza literatury zauważa, że „opozycja swojskości i obcości stanowi jeden z konstytutywnych elementów praktyki i teorii przekładowej”. Zaznacza również, że przewaga jednej $z$ tendencji nie jest stała i zmienia się w czasie (1997: 56). Michał Kłobukowski w rozmowie z Zofią Zaleską (2015: 80-81) stwierdza zaś, że przekład nazw własnych z czasem staje się coraz mniej popularny i może to doprowadzić do zaniechania ich tłumaczenia w ogóle. Przypomnijmy, że antroponimy sztuczne to nazwy, które poza danym tekstem literackim nie posiadają desygnatów. Według Hanny Salich (2012: 49) nazwy, które są niejako neologizmami autorskimi są najbardziej wymagające dla czytelników i dla tłumaczy, ponieważ nie posiadają ekwiwalentów uznanych, czyli takich odpowiedników nazw języka źródłowego, które są stosowane jako ekwiwalent w języku docelowym (Hejwowski 2004: 79-81). Po przeprowadzonej analizie zidentyfikowane zostało jak już wcześniej wspomniano 30 antroponimów sztucznych. Wobec tych form tłumacze zastosowali najczęściej tłumaczenie syntagmatyczne - 18 przypadków w j. francuskim i $19 \mathrm{w}$ angielskim, thumaczenie dosłowne z reprodukcją $-7 \mathrm{w}$ j. francuskim, $6 \mathrm{w}$ angielskim, reprodukcję - po $3 \mathrm{w}$ obu tłumaczeniach, po 1 formie ekwiwalentu funkcjonalnego oraz jedno pominięcie w tekście francuskim oraz jedno dodanie w tekście angielskim.

\subsection{Tłumaczenie syntagmatyczne}

Jak już wspomniano, większość antroponimów sztucznych została przetłumaczona syntagmatycznie, w sposób dosłowny, ponieważ są to formy znaczące. Technika „tłumaczenie syntagmatyczne” jest to zastąpienie nazwy własnej języka wyjściowego przez nazwę własną języka docelowego, która jest ekwiwalentem, jednak w przeciwieństwie do ekwiwalentu uznanego nie była stosowana wcześniej do oznaczenia konkretnej postaci (Hejwowski 2004: 78). Ballard (2001: 31-35) nazywa tę technikę ,traduction plus ou moins littérale”, czyli tłumaczenie bardziej lub mniej dosłowne. Wskazuje jednocześnie, że tłumacz odtwarza w tym przypadku nie tylko zawartość semantyczną nazwy, ale zachowuje również jej strukturę. Jerzy 
Pilch w swojej powieści używa nazw pospolitych lub przymiotników jako nazw własnych, zapisuje je wielką literą. Te formy są przetłumaczone za pomocą ekwiwalentu słownikowego, np. imiona noszone przez przyjaciół głównego bohatera - Jurusia, członków odwyku zostały przetłumaczone dosłownie i zapisane wielką literą, np. Król Cukru - sprzedawał nielegalnie i z wielkim zyskiem cukier w czasach PRL-u, Przodownik Pracy Socjalistycznej pracował w hucie, Najbardziej Poszukiwany Terrorysta Świata miał wygląd recydywisty. Nazwa Przodownik Pracy Socjalistycznej stanowi przykład pełnienia funkcji lokalizacji w czasie, ponieważ odwołuje się do konkretnego epizodu z historii Polski.

(1) Nikt z was nie wyzdrowieje, nikt z was nie przestanie pić (...) ani Król Cukru, ani Przodownik Pracy Socjalistycznej, którego żywy trup nie dalej jak wczoraj znów zawitał w nasze progi, ani Najbardziej Poszukiwany Terrorysta Świata (...) (23)

(1' fr) Pas un d'entre vous ne guérira, pas un n'arrêtera de boire (...) ni le Roi du Sucre, ni le Héros du Travail Socialiste, dont le cadavre ambulant est revenu nous voir pas plus tard qu'hier. Ni le Terroriste le plus Recherché de la Planète (...) (19)

$(1$ ' ang) None of you will recover, none of you will stop drinking. (...) nor the Sugar King, nor the Hero of Socialist Labor, whose living corpse returned to our establishment as recently as yesterday, nor the Most Wanted Terrorist in the World (...) (12)

Rodzajniki określone le i the są obligatoryjne, odpowiednio w języku francuskim i angielskim, w konstrukcjach rodzajnik określony-przymiotnik-nazwa własna, służą one do wyrażenia unikalnego charakteru konkretnego desygnatu (Leroy 2004: 84).

W tekście angielskim dwie nazwy zostały przetłumaczone w sposób mniej neutralny, jak Urugwajka Futbolistka, jedna z kobiet głównego bohatera:

(2) Urugwajka-Futbolistka zawsze miała naszykowany dla mnie elegancki oddział reanimacyjny (...) (117)

(2' fr) L'Uruguayenne Footballeuse avait toujours un élégant service de réanimation à ma disposition (...) (87)

(2" ang) the Uruguayan Center Forward always had a fancy convalescent home for my exclusive use (...) (66)

Jak pokazuje fragment, w tekście angielskim użyto hiponimu - napastnik (center forward), który może wyrażać drapieżność kobiety i jest znacznie mniej neutralny od rzeczownika 
futbolistka. Podobnie w thumaczeniu nazwy doktor Gorzałka, którą nosi miejscowy alkoholik - lekarz:

(3) (...) brał ampułki, siadał na pobliskiej ławce w samym środku rynku, otwierał torbę, wyjmował strzykawkę, igłą przekłuwał spodnie na wysokości uda i dokonywał przez nogawkę subtelnej i wprawnej iniekcji domięśniowej. Wielki doktor Swobodziczka - doktor Morfina, doktor Kodeina, doktor Gorzalka, doktor Nikt. (162)

(3’ fr) Il (...) prenait les ampoules, s'asseyait sur le banc le plus proche, en plein milieu de la grand-place, sortait sa seringue de sa trousse et effectuait une délicate et habile injection intramusculaire en plantant l'aiguille dans sa cuisse, à travers son pantalon. Ce n'était plus le grand docteur Swobodziczka, c'était le

docteur Morphine, le docteur Codéine, le docteur Vodka, le docteur Personne. (122)

(3" ang) Took the ampoules, sat on a nearby bench in the middle of the town square, opened his bag, took out a needle, stuck in through his trouser leg at the level of his thigh and through his pants administered a dexterous and discreet injection into the muscle. The great Dr. Swobodziczka - Dr. Morphine, Dr. Codeine, Dr. Moonshine, Dr. Nobody. (93)

W tekście francuskim zastosowano neutralną nazwę Vodka, w tekście angielskim Moonshine, czyli księżycówka, czyli alkohol pędzony nielegalnie, nocą. Pozostałe pseudonimy doktora (Morfina, Kodeina, Nikt) są przetłumaczone syntagmatycznie po francusku (Morphine, Codéine, Personne) i po angielsku (Morphine, Codeine, Nobody). Nie wszystkie jednak nazwy znaczące zbudowane z nazwy pospolitej zostały przetłumaczone dosłownie.

\subsection{Tłumaczenie syntagmatyczne $\mathrm{z}$ reprodukcją}

Technika „tłumaczenie syntagmatyczne z reprodukcją” występuje w przypadku, kiedy nazwa pospolita i nazwa własna tworzą całość. Nazwa pospolita, która towarzyszy nazwie własnej zostaje przetłumaczona, natomiast nazwa własna pozostaje w swojej oryginalnej formie, ponieważ nie posiada ekwiwalentu i jest egzotyczna dla odbiorców tekstu docelowego:

(4) Posiwiały wilczur doktora Swobodziczki chłepcze swój deputat z blaszanego garnka - doktor od roku nie żyje, ale pies, wierny nawykowi, codziennie zachodzi do gospody, ci, co jeszcze żyją, napełniają jego garnek beczkowym Żywcem sprawiedliwie odlewanym z kufli. (9) 
(4' fr) Le chien-loup au poil blanchi du docteur Swobodziczka lape son salaire en nature dans sa gamelle en fer-blanc ; le docteur est mort depuis un an, mais son chien, fidèle à son habitude, vient tous les jours faire un tour à l'auberge; les clients survivants versent équitablement dans sa gamelle quelques centilitres de leur Żywiec pression. (8)

(4’ ang) Doctor Swobodziczka's graying Alsatian laps up its allotted portion from a tin cup; the doctor died a year ago, but the dog, faithful to its addition, comes to the pub every day, and those who are still alive fill its cup with draft Żywiec poured equitably from a mug. (4)

Swobodziczka to nazwisko stworzone przez pisarza na podstawie gwarowej pieśni Hej swoboda, swobodziczka (z notatek z rozmowy z Jerzym Pilchem, 17.11.2017). Jest to nazwa, która odnosi się bezpośrednio do cech bohatera. Powieściowy doktor jest uzależnionym od alkoholu i lekarstw libertynem. Jednak tłumacze nie zdecydowali się na przetłumaczenie tej nazwy, która wprowadza do tekstu element komizmu oraz spełnia funkcję lokalizacji w przestrzeni - odwołuje się do kultury Śląska Cieszyńskiego i rodzinnych stron autora. Jednak inne nazwisko znaczące - Katastrofa, które nosi kobieta głównego bohatera, zostało przetłumaczone w sposób bezpośredni, potraktowane jak nazwa pospolita i zapisane wielką literą. Ta postać nie potrafi utrzymać porządku i jej cechą charakterystyczną jest robienie bałaganu:

(5) Gdyby Asia Katastrofa kładła klucze na swoim miejscu, kochałbym ją, byłaby miłością mego życia (...) (43)

(5' fr) Si Asia la Catastrophe avait toujours mis les clés à leur place, je l'aurais aimée, elle aurait été l'amour de ma vie (...) (34)

(5”, ang) If Joanna Catastrophe had kept her keys where they were supposed to be, I would have loved her, she would have been the love of my life (...) (24)

\subsubsection{Reprodukcja}

Nazwa własna pozostaje w swojej oryginalnej formie, zostaje przeniesiona z tekstu źródłowego do tekstu docelowego bez zmian. Jest to główna technika egzotyzująca, która wprowadza element obcości, jednak w dzisiejszym zglobalizowanym świecie pewna grupa nazw własnych staje się wspólna dla wielu, odmiennych często kultur. Obcości w przekładzie jest z czasem coraz mniej, co dotyczy głównie nazw własnych, takich jak antroponimy, toponimy autentyczne. Jednak w przypadku antroponimów stworzonych przez autora, czyli nazw 
nieposiadających desygnatów poza światem przedstawionym, reprodukcji ulegają antroponimy nieposiadające relacji znaczeniowej ze swoim desygnatem. Poniższe nazwy zostały stworzone z powodu swojej dźwięczności i nie odnoszą się do cech postaci (z notatek z rozmowy z Jerzym Pilchem, 17.11.2017), a ich desygnatami są bohaterowie epizodyczni.

(6) - A jednak opisywanie stanu duszy po oddaniu stolca wydaje mi się niestosowne - przerwała mu bez przekonania Fanny Kapelmeister, w cywilu nauczycielka historii. (192)

(6’ fr) - Il me paraît tout de même indécent de décrire ses états d'âme après être allé à la selle, le coupa mollement Fanny Kapelmeister, dans le civil, professeur d'histoire. (144)

(6” ang) „But describing the state of your soul after passing a stool seems to me inappropriate," Fanny Kapelmeister, in civilian life a history teacher, interrupted him without conviction. (111)

Podobnie potraktowany został antroponim sztuczny Oyermah, który jest zniekształconym nazwiskiem rzeczywistym Ogerman:

(7) Tak jest: za czasów doktora Swobodziczki wiślańscy samobójcy nie mieli łatwego życia. Straszliwe przekleństwa sypały się na ich uduszone głowy, doktor przeprowadzał brutalną autopsję, obrzucał stygnące zwłoki obelgami, sunął palcem wzdłuż sinej pręgi na szyi młodego Oyermaha i mówił:

- Masz, chłopie, szczęście, masz, chłopie, szczęście, że nie żyjesz, bo chyba bym ciebie zabił. (158)

( $7^{\prime}$ fr) Aussi les suicidés de Wisła n'avaient-ils pas la vie facile du temps du docteur Swobodziczka. D’horribles jurons se répandaient sur leurs têtes étranglées, le docteur menait une autopsie brutale, agonissait d'insultes leurs corps encore tièdes, passait un doigt sur la balafre bleuie marquant le cou du jeune Oyermah en disant: - Tu as de la chance, mon gars. Tu as de la chance d'être mort, sinon je crois bien que je t'aurais tué. (119)

(7" ang) It was true: in Dr. Swobodziczka's times the suicides of Wisła did not have an easy life. Horrendous curses were heaped upon their asphyxiated heads. The doctor conducted brutal autopsies, pouring insults on their bodies as they grew cold; he passed his finger along the blue mark on young Oyermah's neck and said: „You're lucky, you're lucky you're not alive, boy, because if you were, I'd kill you". (91) 
Powyższa nazwa pełni w tekście funkcję aluzyjną. Pisarz zmodyfikował antroponim autentyczny, w ten sposób, że nazwa docelowa nadal przypomina nazwę wyjściową. Odwołuje się w ten sposób do samobójstwa jednego z mieszkańców Wisły - Ogermana (z notatek z rozmowy z Jerzym Pilchem, 17.11.2017). Aluzja jest czytelna jedynie dla wąskiej grupy odbiorców, nawet w tekście oryginalnym.

\subsubsection{Ekwiwalent funkcjonalny}

Technika tłumaczenia jaką jest „ekwiwalent funkcjonalny” polega na przeniesieniu nazwy za pomocą innowacji tłumacza, nie ekwiwalentu uznanego, czy słownikowego. Zadaniem tej innowacji jest przeniesienie sensu danej nazwy, bez dbania o przystającą formę (Hejwowski 2004: 81-82). Pojawia się w analizowanych przekładach zaledwie raz wobec sztucznego antroponimu Siępiło, co ciekawe nie odnosi się on bezpośrednio do żadnej postaci, a jest zastosowany jako figura retoryczna:

(8) - Picie się zaczęło, zaczęło się pić - mówi Janek, a one wybuchają okropnymi śmiechami i wykrzykują:

- Się piło! Się piło! Się piło! Ale kto pił? Siępiło pił? (147)

(8' fr) - La boisson, dit Janek. La bouteille. Elles éclatent alors d'un rire terrible et poussent des clameurs :

- La boisson! La bouteille! Qui est-ce qui buvait ? C'est la bouteille qui buvait? (111)

(8" ang) ,The drinking started, the drinking began," says Janek, and they laugh their awful laughs and exclaim:

„The drinking began! The drinking started! But who was doing the drinking?

Was thedrinkingstarted drinking?" (84)

Pielęgniarki obsługujące pacjentów na odwyku żartują sobie z jednego z nich. Siępiło znaczy tyle co ktoś, nie ja. W przekładzie francuskim użyto nazwy pospolitej - butelka, a w języku angielskim neologizmu w formie nazwy pospolitej, złożonego z rodzajnika określonego - the, rzeczownika - drinking (picie) oraz czasownika - started (rozpoczęło się). Przykład ten pokazuje, że sens został zachowany przy użyciu dwóch różnych ekwiwalentów funkcjonalnch.

\subsubsection{Pominięcie}

Technika jaką jest „pominięcie” pojawia się tylko raz w przekładzie francuskim i dotyczy jedynie części nazwy: 
(9) Don Juan Ziobro - fryzjer, a w dodatku muzyk - jak zwykł się przedstawiać, pochodził z nadzwyczaj muzykalnej rodziny. (181)

(9' fr) Don Juan, coiffeur et aussi musicien, comme il avait coutume de se présenter, était d'une famille très musicienne. (136)

(9"' ang) Don Juan the Rib - hairdresser and additionally musician, as he was wont to introduce himself - came from a most musical family. (104)

Don Juan Ziobro to jeden z pacjentów szpitala w Tworkach, uczestniczy w odwyku i posiada wszystkie cechy literackiego Don Juana, jest kochliwy, ma słabość do wszystkich kobiet, nazwa spełnia więc funkcję aluzyjną. Jednak Ziobro według zamysłu pisarza nie jest nazwą znaczącą a jedynie dźwięcznym uzupełnieniem nazwy na wzór filmowego Don Juana de Marco (z notatek z rozmowy z Jerzym Pilchem, 17.11.2017). Stąd przypuszczać można, że ten obcy element w przekładzie francuskim wydał się zbędny. Z kolei w przekładzie angielskim nazwa pojawia się w całości. Rzeczownik ziobro odwołuje się do gwary Śląska Cieszyńskiego i znaczy żebro (Wronicz 2010: 382), stąd wynika, że nazwa może pełnić nie tylko funkcję aluzyjną, ale rówież lokalizacyjną i odwoływać się do konkretnego regionu Polski.

\subsubsection{Dodanie}

Tylko raz w angielskim przekładzie zastosowane zostało „dodanie”:

(10) Kolumb Odkrywca co najmniej od dwudziestu lat płynął wpław przez morze ciemności, zachłysnąwszy się nawet pięćdziesiątką bezkresnego przestworu wód oceanicznych, niezmiennie popadał w mordercze, nie kończące się ochlaje. (60)

(10’ fr) Il y avait au moins vingt ans que Colomb le Découvreur traversait une mer de ténèbres à la nage ; après avoir englouti ne fût-ce qu'une petite vodka à l'étendue infinie des eaux océaniques, il sombrait invariablement dans une cuite ininterrompue, à en crever. (47)

(10" ang) Christopher Columbus the Explorer had been sailing across the sea of darkness for at least twenty years; when he accidentally swallowed even a single shot of the boundless expanse of oceanic waters, he invariably descended into a murderous unending jag. (34)

Dodanie polega w tym przypadku na dopisaniu imienia Christopher do całej nazwy. Kolumb Odkrywca został sklasyfikowany jako nazwa sztuczna, ponieważ nosi ją bohater powieści, 
jeden z pacjentów szpitala, desygnat nazwy należy do świata przedstawionego i w sposób ironiczny przywołuje postać historyczną, jaką jest Krzysztof Kolumb.

\section{Wnioski}

W przekładzie antroponimów sztucznych z powieści „Pod Mocnym Aniołem” Jerzego Pilcha dominującą techniką okazało się być tłumaczenie syntagmatyczne; na 30 nazw własnych $\mathrm{z}$ tekstu oryginalnego za pomocą tej techniki przetłumaczonych zostało 18 antroponimów na język francuski i 19 na język angielski. Pozostałe zidentyfikowane techniki to kolejno: tłumaczenie z reprodukcją, reprodukcja, ekwiwalent funkcjonalny, pominięcie i dodanie. Można stwierdzić, że większość kategorii nazw własnych determinuje wybór konkretnej techniki przekładu. Jeśli nazwa jest znacząca zostaje przetłumaczona. To, czy nazwa zbudowana jest z samej nazwy własnej, czy towarzyszy jej nazwa pospolita wpływa na wybór techniki. Nazwa pospolita i nazwa własna są najczęściej przełożone za pomocą reprodukcji $\mathrm{z}$ tłumaczeniem. Z kolei reprodukcja pojawia się wtedy, kiedy nazwa jest wspólna dla kultury polskiej, francuskiej i angielskiej jak Don Juan, lub wręcz przeciwnie, jeśli jest nieznana i obca jak Oyermah. Ekwiwalent funkcjonalny użyty został jedynie raz, co może świadczyć o tym, że nazwy nie są jednak tak egzotyczne i nie stanowią bariery dla zastosowania innych technik. Wobec jednej nazwy własnej złożonej można zastosować więcej niż jedną technikę przekładu. Mimo, że zbadano dwa przekłady na języki należące do dwóch różnych grup językowych, to użyte techniki tłumaczenia na język francuski i język angielski są niemal identyczne. Świadczy to o tym, że normy językowe są takie same i słabsze od nazwy własnej języka wyjściowego, ponieważ to ona sama, jej budowa i rodzaj dyktują niejako określone jej traktowanie.

\section{Aneks}

\begin{tabular}{|l|l|l|l|l|}
\hline \multicolumn{1}{|c|}{ Pl } & \multicolumn{1}{|c|}{ Fr } & \multicolumn{1}{c|}{ technika } & \multicolumn{1}{c|}{ Ang } \\
\hline $\begin{array}{l}\text { doktor } \\
\text { Swobodziczka } \\
\text { str. 9 }\end{array}$ & $\begin{array}{l}\text { le docteur } \\
\text { Swobodziczka str. 8 }\end{array}$ & $\begin{array}{l}\text { thumaczenie } \\
\text { syntagmatyczne + } \\
\text { reprodukcja }\end{array}$ & $\begin{array}{l}\text { Doctor } \\
\text { Swobodziczka str. 4 }\end{array}$ & $\begin{array}{l}\text { thumaczenie } \\
\text { syntagmatyczne } \\
\text { + reprodukcja }\end{array}$ \\
\hline $\begin{array}{l}\text { Kolumb } \\
\text { Odkrywca 23 }\end{array}$ & $\begin{array}{l}\text { Colomb le } \\
\text { Découvreur 19 }\end{array}$ & $\begin{array}{l}\text { thumaczenie } \\
\text { syntagmatyczne }\end{array}$ & $\begin{array}{l}\text { Christopher } \\
\text { Columbus the } \\
\text { Explorer 12 }\end{array}$ & $\begin{array}{l}\text { dodanie + } \\
\text { tłumaczenie } \\
\text { syntagmatyczne }\end{array}$ \\
\hline $\begin{array}{l}\text { Krzysztof } \\
\text { Kolumb } \\
\text { Odkrywca 59 }\end{array}$ & $\begin{array}{l}\text { Christophe Colomb } \\
\text { le Découvreur 46 }\end{array}$ & $\begin{array}{l}\text { thumaczenie } \\
\text { syntagmatyczne }\end{array}$ & $\begin{array}{l}\text { Christopher } \\
\text { Columbus the } \\
\text { Explorer 33 }\end{array}$ & $\begin{array}{l}\text { tłumaczenie } \\
\text { syntagmatyczne }\end{array}$ \\
\hline
\end{tabular}




\begin{tabular}{|c|c|c|c|c|}
\hline $\begin{array}{l}\text { Szymon Sama } \\
\text { Dobroć } 23\end{array}$ & $\begin{array}{l}\text { Szymon la Bonté } \\
\text { Même } 19\end{array}$ & $\begin{array}{l}\text { reprodukcja + } \\
\text { thumaczenie } \\
\text { syntagmatyczne }\end{array}$ & $\begin{array}{l}\text { Simon Pure Godness } \\
112\end{array}$ & $\begin{array}{l}\text { thumaczenie } \\
\text { syntagmatyczne }\end{array}$ \\
\hline $\begin{array}{l}\text { Don Juan Ziobro } \\
23\end{array}$ & Don Juan 19 & $\begin{array}{l}\text { pominięcie + } \\
\text { reprodukcja }\end{array}$ & Don Juan the Rib 12 & $\begin{array}{l}\text { reprodukcja }+ \\
\text { tłumaczenie } \\
\text { syntagmatyczne }\end{array}$ \\
\hline Don Juan 144 & Don Juan 107 & reprodukcja & Don Juan 82 & reprodukcja \\
\hline Król Cukru 23 & le Roi du Sucre 19 & $\begin{array}{l}\text { thumaczenie } \\
\text { syntagmatyczne }\end{array}$ & the Sugar King 12 & $\begin{array}{l}\text { tłumaczenie } \\
\text { syntagmatyczne }\end{array}$ \\
\hline $\begin{array}{l}\text { Przodownik } \\
\text { Pracy } \\
\text { Socjalistycznej } \\
23\end{array}$ & $\begin{array}{l}\text { le Héros du Travail } \\
\text { Socialiste } 19\end{array}$ & $\begin{array}{l}\text { thumaczenie } \\
\text { syntagmatyczne }\end{array}$ & $\begin{array}{l}\text { the Hero of Socialist } \\
\text { Labor } 12\end{array}$ & $\begin{array}{l}\text { thumaczenie } \\
\text { syntagmatyczne }\end{array}$ \\
\hline $\begin{array}{l}\text { panie } \\
\text { Przodowniku } 68\end{array}$ & monsieur le Héros 53 & $\begin{array}{l}\text { thumaczenie } \\
\text { syntagmatyczne }\end{array}$ & Mr. Hero 39 & $\begin{array}{l}\text { tłumaczenie } \\
\text { syntagmatyczne }\end{array}$ \\
\hline $\begin{array}{l}\text { Najbardziej } \\
\text { Poszukiwany } \\
\text { Terrorysta } \\
\text { Świata 23 }\end{array}$ & $\begin{array}{l}\text { le Terroriste le plus } \\
\text { Recherché de la } \\
\text { Planète } 19\end{array}$ & $\begin{array}{l}\text { thumaczenie } \\
\text { syntagmatyczne }\end{array}$ & $\begin{array}{l}\text { the Most Wanted } \\
\text { Terrorist in the World } \\
12\end{array}$ & $\begin{array}{l}\text { thumaczenie } \\
\text { syntagmatyczne }\end{array}$ \\
\hline $\begin{array}{l}\text { Królowa Kentu } \\
23\end{array}$ & la Reine du Kent 19 & $\begin{array}{l}\text { thumaczenie } \\
\text { syntagmatyczne + } \\
\text { reprodukcja }\end{array}$ & the Queen of Kent 12 & $\begin{array}{l}\text { tłumaczenie } \\
\text { syntagmatyczne } \\
+ \text { reprodukcja }\end{array}$ \\
\hline $\begin{array}{l}\text { Fanny } \\
\text { Kapelmeister } 23\end{array}$ & $\begin{array}{l}\text { Fanny Kapelmeister } \\
19\end{array}$ & reprodukcja & $\begin{array}{l}\text { Fanny Kapelmeister } \\
12\end{array}$ & reprodukcja \\
\hline $\begin{array}{l}\text { terapeuta } \\
\text { Mojżesz alias Ja } \\
\text { Alkohol } 30\end{array}$ & $\begin{array}{l}\text { le psy Moïse, alias } \\
\text { Moi, l'Alcool... } 23\end{array}$ & $\begin{array}{l}\text { thumaczenie } \\
\text { syntagmatyczne }\end{array}$ & $\begin{array}{l}\text { the male therapist } \\
\text { Moses Alias I } \\
\text { Alcohol } 16\end{array}$ & $\begin{array}{l}\text { thumaczenie } \\
\text { syntagmatyczne }\end{array}$ \\
\hline $\begin{array}{l}\text { Asia Katastrofa } \\
43\end{array}$ & $\begin{array}{l}\text { Asia la Catastrophe } \\
34\end{array}$ & $\begin{array}{l}\text { reprodukcja }+ \\
\text { thumaczenie } \\
\text { syntagmatyczne }\end{array}$ & $\begin{array}{l}\text { Joanna Catastrophe } \\
24\end{array}$ & $\begin{array}{l}\text { reprodukcja }+ \\
\text { tłumaczenie } \\
\text { syntagmatyczne }\end{array}$ \\
\hline $\begin{array}{l}\text { państwo } \\
\text { Katastrofowie } 47\end{array}$ & $\begin{array}{l}\text { M. et Mme } \\
\text { Catastrophe } 37\end{array}$ & $\begin{array}{l}\text { tłumaczenie } \\
\text { syntagmatyczne }\end{array}$ & $\begin{array}{l}\text { the Catastrophe } \\
\text { family } 26\end{array}$ & $\begin{array}{l}\text { tłumaczenie } \\
\text { syntagmatyczne }\end{array}$ \\
\hline $\begin{array}{l}\text { pan Katastrofa } \\
48\end{array}$ & M. Catastrophe 38 & $\begin{array}{l}\text { thumaczenie } \\
\text { syntagmatyczne }\end{array}$ & Mr. Catastrophe 27 & $\begin{array}{l}\text { tłumaczenie } \\
\text { syntagmatyczne }\end{array}$ \\
\hline $\begin{array}{l}\text { pani } \\
\text { Katastrofowa } 48\end{array}$ & Mme Catastrophe 38 & $\begin{array}{l}\text { thumaczenie } \\
\text { syntagmatyczne }\end{array}$ & Mrs. Catastrophe 27 & $\begin{array}{l}\text { tłumaczenie } \\
\text { syntagmatyczne }\end{array}$ \\
\hline $\begin{array}{l}\text { Zwodnicza } \\
\text { Gwiazda } \\
\text { Filmowa } 117\end{array}$ & $\begin{array}{l}\text { la Vedette de } \\
\text { Cinéma Décevante } \\
86\end{array}$ & $\begin{array}{l}\text { thumaczenie } \\
\text { syntagmatyczne }\end{array}$ & $\begin{array}{l}\text { the Seductive Movie } \\
\text { Star } 66\end{array}$ & $\begin{array}{l}\text { thumaczenie } \\
\text { syntagmatyczne }\end{array}$ \\
\hline $\begin{array}{l}\text { Urugwajka- } \\
\text { Futbolistka } 117\end{array}$ & $\begin{array}{l}\text { l'Uruguayenne } \\
\text { Footballeuse } 86\end{array}$ & $\begin{array}{l}\text { thumaczenie } \\
\text { syntagmatyczne }\end{array}$ & $\begin{array}{l}\text { the Uruguayan Center } \\
\text { Forward } 66\end{array}$ & $\begin{array}{l}\text { tłumaczenie } \\
\text { syntagmatyczne }\end{array}$ \\
\hline $\begin{array}{l}\text { Joacha Postrach } \\
\text { Tworek } 117\end{array}$ & $\begin{array}{l}\text { Joanna la Terreur de } \\
\text { Tworki } 86\end{array}$ & $\begin{array}{l}\text { thumaczenie } \\
\text { syntagmatyczne + } \\
\text { reprodukcja }\end{array}$ & $\begin{array}{l}\text { Joanna Scourge of } \\
\text { the Asylum } 66\end{array}$ & $\begin{array}{l}\text { reprodukcja }+ \\
\text { tłumaczenie } \\
\text { syntagmatyczne }\end{array}$ \\
\hline
\end{tabular}




\begin{tabular}{|c|c|c|c|c|}
\hline $\begin{array}{l}\text { Bacha Maklerka } \\
117\end{array}$ & $\begin{array}{l}\text { Barbara la Grosse } \\
\text { Courtière } 87\end{array}$ & $\begin{array}{l}\text { reprodukcja }+ \\
\text { tłumaczenie } \\
\text { syntagmatyczne }\end{array}$ & Barb the Broker 66 & $\begin{array}{l}\text { tłumaczenie } \\
\text { syntagmatyczne }\end{array}$ \\
\hline $\begin{array}{l}\text { Zupełnie } \\
\text { Nieodpowiedzial } \\
\text { na Smarkula } 117\end{array}$ & $\begin{array}{l}\text { la Gamine } \\
\text { Totalement } \\
\text { Irresponsable } 87\end{array}$ & $\begin{array}{l}\text { thumaczenie } \\
\text { syntagmatyczne }\end{array}$ & $\begin{array}{l}\text { the Utterly } \\
\text { Irresponsable Minx } \\
66\end{array}$ & $\begin{array}{l}\text { tłumaczenie } \\
\text { syntagmatyczne }\end{array}$ \\
\hline Siępiło pił? 147 & $\begin{array}{l}\text { c'est la bouteille qui } \\
\text { buvait? } 111\end{array}$ & $\begin{array}{l}\text { ekwiwalent } \\
\text { funkcjonalny }\end{array}$ & $\begin{array}{l}\text { was thedrinkingstar- } \\
\text { ted drinking? } 84\end{array}$ & $\begin{array}{l}\text { ekwiwalent } \\
\text { funkcjonalny }\end{array}$ \\
\hline Konsul 158 & le Consul 118 & $\begin{array}{l}\text { tłumaczenie } \\
\text { syntagmatyczne }\end{array}$ & Consul 90 & $\begin{array}{l}\text { tłumaczenie } \\
\text { syntagmatyczne }\end{array}$ \\
\hline Oyermah 158 & Oyermah 119 & reprodukcja & Oyermah 91 & reprodukcja \\
\hline $\begin{array}{l}\text { doktor Morfina } \\
162\end{array}$ & $\begin{array}{l}\text { le docteur Morphine } \\
122\end{array}$ & $\begin{array}{l}\text { thumaczenie } \\
\text { syntagmatyczne }\end{array}$ & Dr. Morphine 93 & $\begin{array}{l}\text { tłumaczenie } \\
\text { syntagmatyczne }\end{array}$ \\
\hline $\begin{array}{l}\text { doktor Kodeina } \\
162\end{array}$ & $\begin{array}{l}\text { le docteur Codéine } \\
122\end{array}$ & $\begin{array}{l}\text { thumaczenie } \\
\text { syntagmatyczne }\end{array}$ & Dr. Codeine 93 & $\begin{array}{l}\text { tłumaczenie } \\
\text { syntagmatyczne }\end{array}$ \\
\hline $\begin{array}{l}\text { doktor Gorzałka } \\
162\end{array}$ & $\begin{array}{l}\text { le docteur Vodka } \\
122\end{array}$ & $\begin{array}{l}\text { tłumaczenie } \\
\text { syntagmatyczne }\end{array}$ & Dr. Moonshine 93 & $\begin{array}{l}\text { tłumaczenie } \\
\text { syntagmatyczne }\end{array}$ \\
\hline doktor Nikt 162 & $\begin{array}{l}\text { le docteur Personne } \\
122\end{array}$ & $\begin{array}{l}\text { tłumaczenie } \\
\text { syntagmatyczne }\end{array}$ & Dr. Nobody 93 & $\begin{array}{l}\text { tłumaczenie } \\
\text { syntagmatyczne }\end{array}$ \\
\hline $\begin{array}{l}\text { Stary Król Kentu } \\
178\end{array}$ & $\begin{array}{l}\text { le Vieux Roi du Kent } \\
133\end{array}$ & $\begin{array}{l}\text { tłumaczenie } \\
\text { syntagmatyczne + } \\
\text { reprodukcja }\end{array}$ & $\begin{array}{l}\text { the Old King of Kent } \\
102\end{array}$ & $\begin{array}{l}\text { tłumaczenie } \\
\text { syntagmatyczne } \\
\text { + reprodukcja }\end{array}$ \\
\hline
\end{tabular}

\section{Bibliografia}

Ballard, Michael (2001) Le nom propre en traduction. Paris: Ophrys.

Dąmbska-Prokop, Urszula (2010) Nowa encyklopedia przekładoznawstwa. Kielce: Wyższa Szkoła Umiejętności im. Stanisława Staszica.

Hejwowski, Krzysztof (2004) Kognitywno-komunikacyjna teoria przekładu. Warszawa: Wydawnictwo Naukowe PWN.

Kleiber, Georges (2007) „Sur le rôle cognitif des noms propres”. Cahiers de Lexicologie, 91; $153-167$.

Kosyl, Czesław (1992) Nazwy własne $w$ prozie Jarosława Iwaszkiewicza. Lublin: Wydawnictwo Uniwersytetu Marii Curie-Skłodowskiej.

Kosyl, Czesław (1993) „Główne nurty nazewnictwa literackiego”. [W:] Maria Biolik (red.) Onomastyka literacka. Olsztyn: Wydawnictwo Wyższej Szkoły Pedagogicznej; 67-100. Kosyl, Czesław (1993) „Nazwy osobowe”. [W:] Jerzy Bartmiński (red.) Encyklopedia kultury polskiej XX wieku. Wrocław: Wiedza o kulturze; 423-437.

Leroy, Sarah (2004) Le nom propre en français. Paris: Ophrys. 
Łukasiewicz, Małgorzata (2017) Pięć razy o przekładzie. Kraków-Gdańsk: Karakter, Instytut Kultury Miejskiej.

Pilch, Jerzy (2000) Pod Mocnym Aniołem. Kraków: Wydawnictwo Literackie.

Pilch, Jerzy (2003) Sous l'aile d'un ange. (tłum.) Laurence Dyèvre. Paris: Noir sur Blanc.

Pilch, Jerzy (2009) The Mighty Angel. (tłum.) Bill Johnston. Rochester: Open Letter.

Salich, Hanna (2012) „Problemy tłumaczeniowe związane z przekładem neologizmów autorskich. Wroniec Jacka Dukaja - analiza tekstu oryginału”. [W:] Roman Lewicki (red.) Przekład, język, kultura III. Lublin: Wydawnictwo Uniwersytetu Marii CurieSkłodowskiej; 49-60.

Święch, Jerzy (1997) „Przekład na warsztacie badacza literatury”. [W:] Przekład literacki. Teoria. Historia. Wspótczesność. Warszawa: Wydawnictwo Naukowe PWN; 51-66.

Wronicz, Jadwiga (2010) Gwarowy Słownik Śląska Cieszyńskiego. Ustroń: Galeria „Na Gojach".

Zaleska, Zofia (2015) Przejęzyczenie. Rozmowy o przekładzie. Wołowiec: Wydawnictwo Czarne.

Notatki z rozmowy z Jerzym Pilchem, 17.11.2017. 